\title{
PENDAMPINGAN USAHA PENGEMBANGAN PRODUK KUDAPAN DENGAN BAHAN JAMBU BIJI DI DESA KEBARON SIDOARJO
}

\author{
Hari Minantyo $^{1)}$, Prasetyon Sepsi Winarno(2), Moses Soediro ${ }^{3)}$, Baswara Yua Kristama ${ }^{4)}$ \\ 1,2,3,4Fakultas Pariwisata Universitas Ciputra Surabaya \\ Email: hari.minantyo@ciputra.ac.id ${ }^{1}$ sepsi@ciputra.ac.id ${ }^{2} \cdot$ msudiro@ciputra.ac.id ${ }^{3}$. \\ Baswara.kristanto@ciputra.ac.id
}

\begin{abstract}
Abstrak
Pengembangan Usaha dalam bidang kuliner bisa dilakukan dengan cara menggali celah-celah hasil tanaman pangan yang banyak melimpah dan masih belum dilakukan oleh para pemerhati usaha kuliner khususnya. Hasil olah tanaman pertanian yang sudah dipanen melimpah sehingga terjadi kelebihan jumlah dan belum bisa tertangani secara benar yang mengakibatkan terbuangnya hasil pertanian tersebut karena kurangnya pengalaman untuk membuat produk yang kreatif. Desa Kebaron merupakan salah satu desa wisata kebun jambu di Sidoarjo yang mempunyai hasil pertanian jambu biji dengan hasil panen yang sangat melimpah. Kendala yang dihadapi adalah ketika musim panen tiba dan hasil panen jambu sangat melimpah, meskipun banyak pengunjung yang datang, masih ada kelebihan jambu yang terbuang begitu saja.Pentingnya dalam menciptakan ide untuk menciptakan kudapan yang kreatif, aman dan sehat dengan membuat donat dengan menggunakan bahan dasar dari jambu biji yang berwarna merah. Dengan adanya pendampingan yang sudah dilakukan, peserta sangat senang mendapatkan pengetahuan dan sekalian ada penerapan dalam bentuk praktek membua produk donat dengan menggunakan bahan jambu biji.
\end{abstract}

Kata Kunci: Pendampingan pelatihan, Donat, Jambu Biji, Desa Kebaron

\begin{abstract}
The purpose of this development is to utilize abundant guava fruit to be creative snack like doughnut. Business development in culinary field can be done by exploring the gaps of great abundant result food crop and still have not been done especially by the observers of culinary business. The result of processing agricultural crops that has been harvested abundant so that resulting in an excess amount and cannot be handled correctly causes the waste of these agricultural products due to the lack experience to make creative product. Kebaron village is one of the guava garden tourism villages in Sidoarjo that has guava seed agricultural crop with abundant crop yield. The obstacles that are faced are when there is harvesting time and abundant guava yield, although a lot of visitors come, there are still wasted excessive guavas like that. It is important in creating idea to create creative snack, safe and healthy by making doughnut using basic ingredient of guava seeds. The result of doughnut creation that is made is really liked by the participants who follow enthusiastically. With tehe assistance that has been done, participants are very happy to get knowlwdge and at the same time apply in the form of the practice of making donut products using guava ingredients.
\end{abstract}

Keywords: Training Companion, Guava Seed Doughnut, Kebraon Village 


\section{PENDAHULUAN}

Pengembangan Usaha dalam bidang kuliner bisa dilakukan dengan cara menggali celah-celah hasil tanaman pangan yang banyak melimpah dan masih belum dilakukan oleh para pemerhati usaha kuliner khususnya. Hasil olah tanaman pertanian yang sudah dipanen melimpah sehingga terjadi kelebihan jumlah dan belum bisa tertangani secara benar yang mengakibatkan terbuangnya hasil pertanian tersebut karena kurangnya pengalaman untuk membuat produk yang kreatif.

Jambu biji ( Psidium guajava) bukan merupakan tanamanasli Indonesia. Tanaman ini pertama kali ditemukan di AmerikaTengah oleh Nikolai Ivanovich Vavilov saat melakukan ekspedisike beberapa Negara di Asia, Afrika, Eropa, Amerika Selatan, dan Uni Soviet antara tahun 1887 - 1942. Seiring dengan berjalannya waktu, jambu biji menyebar di beberapa Negara seperti Thailand,Taiwan, Indonesia, Jepang, Malaysi a, dan Australia (Parimin,2005.

Desa Kebaron merupakan salah satu desa wisata kebun jambu di Sidoarjo yang mempunyai hasil pertanian jambu biji dengan hasil panen yang sangat melimpah. Jenis jambu biji yang ditanam dengan luas area 5,5 hektar di desa Kebaron Sidoarjo dengan jumlah tanaman jambu sekitar 1200 pohon. Adapun jenis jambu yang ditanam di kebun tersebut ada lima jenis jembu biji diantaranya adalah jambu biji jenis Kristal warnanya putih, jambu biji jenis Bangkok yang berwarna merah, jambu biji jenis lokal berwarna ungu, jambu biji jenis sukun berwarna putih.

Desa Kebaron dipimpin oleh Bapak Haji Mansur sebagai Kepala Desa. Proses menanam jambu dengan sistim menyewa lahan persawahan dikelola oleh bapak Mansur dengan dibantu oleh beberapa karyawannya. Sebelum menanam jambu ini lahannya ditanami garbis atau semangka. Mulai tahun 2016 baru beralih dengan menanam jambu. Dengan tekun menanam jambu dan berhasil berbuah yang sangat melimpah akhirnya desa ini menjadi terkenal dan banyak dikunjungi oleh para wisatawan yang ingin menikmati suasana di kebun jambu sambil menikmati enaknya metik jambu yang langsung bisa dimakan.

Kendala yang dihadapi oleh Bapak Haji Mansur ketika musim panen tiba dan hasil panen jambu sangat melimpah, meskipun banyak pengunjung yang datang, masih ada kelebihan jambu yang terbuang begitu saja.

Adanya kendalayang dihadapi dengan hasil panen jambu yang melimpah dan belum bisa dimanfaatkan, maka perlu kerja sama dengan berbagai pihak yang terkait untuk dijadikan mitra kerja.

Tujuan pendampingan dalam pengembangan produk kudapan dengan menggunakan bahan dasar jambu ini adalah untuk:

1. Membantu mitra dalam memanfaatkan hasil panen jambu biji yang melimpah untuk dijadikan produk olahan yang bisa menunjang wisata petik jambu di desa tersebut.

2. Membantu masyarakat di desa Kebaron untuk ikut aktif mengembangkan produk kudapan dengan bahan dasar jambu biji.

Berdasarkan analisis yang dilakukan dengan mitra, permasalahan prioritas mitra yang perlu segera diatasi adalah sebagai berikut:

1. Segi pengetahuan, mengenai pembinaan manajemen pembuatan olahan makanan/kudapan/ minuman yang kreatif, aman dan sehatdengan menggunakan bahan dasar dari jambu biji kepada masyarakat di desa Kebaron Tulangan Sidoarjo.

2. Segi aktifitas, Pendampingan untuk membuat produk-produk olahan makanan/kudapan/ minuman yang kreatif dengan menggunakan bahan dasar dari jambu biji.

Berdasarkan hasil analisis yang dilakukan bersama mitra, solusi yang ditawarkan adalah: 
1. Untuk segi pengetahuan, memberikan pemahaman tentang manajemen pembuatan olahan makanan/kudapan/minuman yang kreatif, aman, sehat dengan menggunakan bahan dasar dari jambu biji.

2. Untuk segi aktifitas, pendampingan cara memberikan pelatihan praktek langsung membuat olahan kudapan yang kreatif berupa donat dengan bahan dasar dari buah jambu biji yang berwarna merah.

\section{METODE PELAKSANAAN}

Pelaksanaan kegiatan pelatihan pada masyarakat di desa Kebaron Tulangan Sidoarjo sebagai berikut:

1. Memberikan penjelasan dalam bentuk presentasi tentang manajemen bagaimana cara menerapkan personal hygiene terhadap penjamah makanan pada saat membuat makanan, cara menangani dan menyimpan bahan makanan yang benar, cara memasak yang benar, cara menyimpan makanan yang benar.

2. Diberikan pelatihan cara menghitung biaya bahan untuk produksi dan harga penjualannya.

3. Demostrasi cara membuat produk dengan menggunakan bahan dari jambu biji untuk dijadikan kudapan berupa donat.

4. Memberikan pendampingan kepada peserta pada saat membuat kudapan berupa donat yag menggunakan bahan jambu biji yang berwarna merah.

5. Memberikan evaluasi setelah peserta mengikuti praktek membuat kudapan donat bedasarkan hasil produk dari masing-masing kelompok.Adapun tahapan kegiatan dalam pelatihan ini adalah
6.

\begin{tabular}{c|l|l} 
No. & Keterangan & \multicolumn{1}{|c}{$\begin{array}{c}\text { Waktu } \\
\text { Pelaksanaan }\end{array}$} \\
\hline 1. & $\begin{array}{l}\text { Pembuatan } \\
\text { Proposal }\end{array}$ & Juni 2019 \\
\hline 2. & $\begin{array}{l}\text { Koordinasi } \\
\text { Pelaksanaan }\end{array}$ & Juli 2019 \\
\hline 3. & $\begin{array}{l}\text { Pelatihan } \\
\text { manajemen } \\
\text { dan sanitasi } \\
\text { hygiene }\end{array}$ & Agustus 2019 \\
\hline 4. & $\begin{array}{l}\text { Pendampingan } \\
\text { Praktek }\end{array}$ & Agustus 2019 \\
\hline
\end{tabular}

\section{HASIL DAN PEMBAHASAN}

Pelaksanaan pengabdian masyarakat dimulai dengan persiapan pelaksana melakukan kunjungan ke desa Kebaron Tulangan Sidoarjo dengan menemui Kepala Desa Kebaron Tulangan Sidoarjo Bapak Mansur dengan jajarannya untuk mengadakan wawancara terkait dengan hasil pertanian dari kebun jambu, dan permasalahan-permasalahan yang dihadapi untuk hasil panen di kebun jambu. Hasil dari pelaksanaan pendampingan kepada masyarakat di desa Kebaron Tulangan Sidoarjo dengan kami sebagai mitra kerjasama bisa berjalan sesuai dengan keinginan kepala desa dan warga di desa Kebaron Tulangan Sidoarjo dengan memulai memberikan pelatihan dan pendampingan untuk membuat kreasi produk olahan kudapan berupa donat dengan menggunakan bahan jambu biji yang berwarna merah dari hasil tanamannya yang melimpah. Hasil pelatihan ini nanti ke depannya akan digunakan sebagai penunjang wisata petik jambu yang sudah rutin diadakan di tempat tersebut. Pendampingan pelatihan olahan produk jambu biji di desa Kebaron ini akan belanjut untuk produk-produk olahan lainnya untuk ke depannya. Pembahasan hasil dari pendampingan dibuktikan dalam perincian di bawah ini dalam bentuk foto kegiatan. 

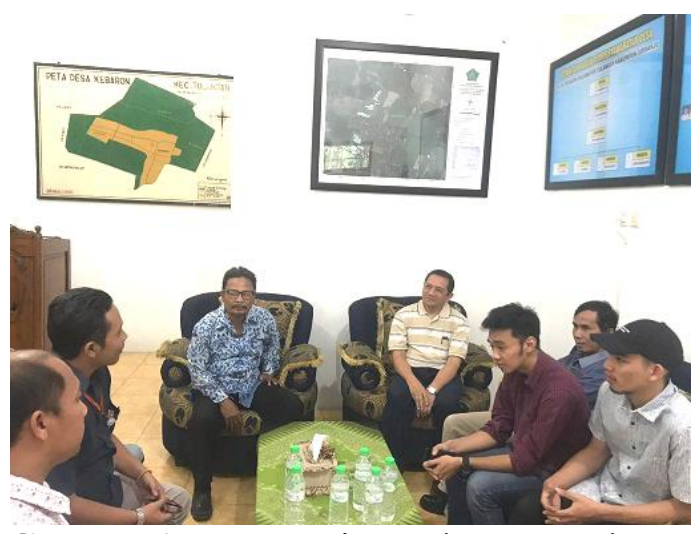

Gambar 1 : Menemui Kepala Desa Kebaron

Tulangan Sidoarjo, Bapak Haji Mansur

Acara dilanjutkan dengan melakukan kenjungan langsung menuju ke kebun jambu bersama dengan Bapak Haji Mansur bersama perangkat desa untuk melihat buah jambu yang ada di kebun jambu di desa Kebaron Tulangan Sidoarjo.

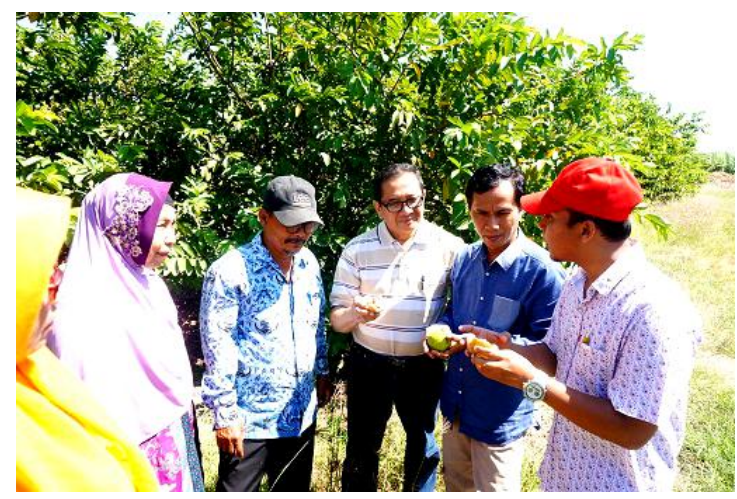

Gambar 2 : Penjelasan Jenis Jambu oleh Perangkat Desa Kebaron Tulangan Sidoarjo

Pada saat peninjauan ke kebun jambu biji di desa Kebaron Tulangan Sidoarjo membahas masalah hasil panen jambu biji yang melimpah pada saat musim panen.

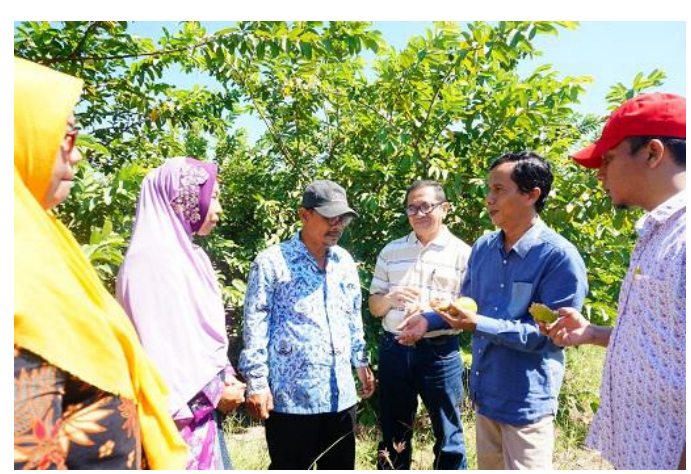

Gambar 3: Membahas Kuliner Kreatif dengan Bahan Dasar dari Jambu Biji

Presentasi penjelasan kepada masyarakat desa Kebaron Tulangan Sidoarjo tentang sanitasi hygiene untuk penjamah makanan, cara menangani, menyimpan bahan makanan dan cara menyimpan makanan yang benar.

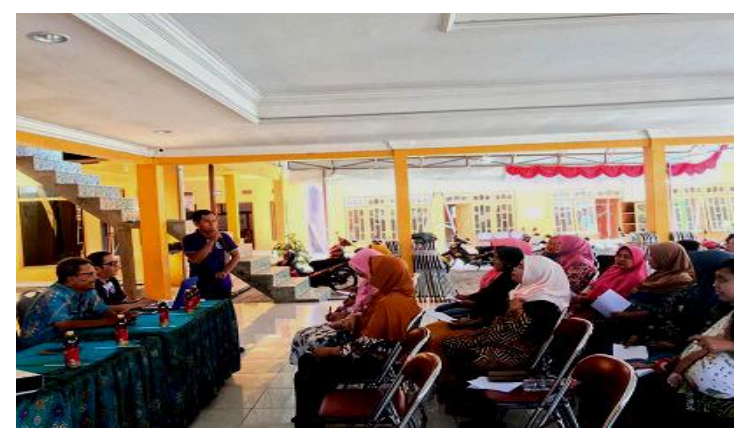

Gambar 4 : Penjelasan tentang Sanitasi Hygiene Bagi Penjamah Makanan

Presentasi penjelasan kepada masyarakat desa Kebaron Tulangan Sidoarjo tentang manajemen untuk usaha kuliner dengan membuat produk kreatif kudapan donat dengan bahan dasar jambu biji yang berwarna merah.

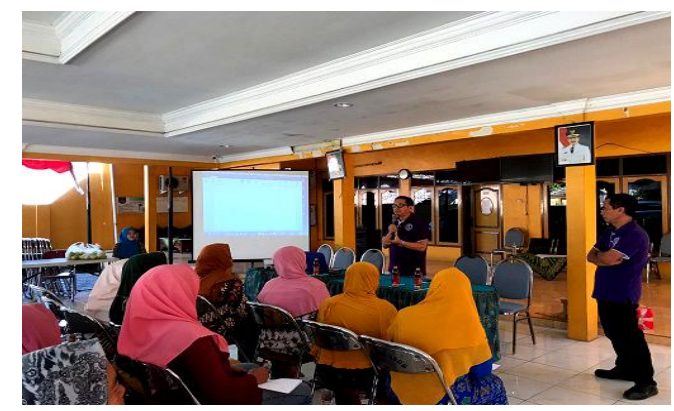

Gambar 5 : Presentasi tentang Menghitung Harga Jual Donat Bahan DasarJambu Biji 
Praktek pelatihan membuat produk kudapan kreatif donat dengan menggunakan bahan dasar daribuah jambu biji di desa Kebaron Tulangan Sidoarjo diikuti peserta dengan antisias.

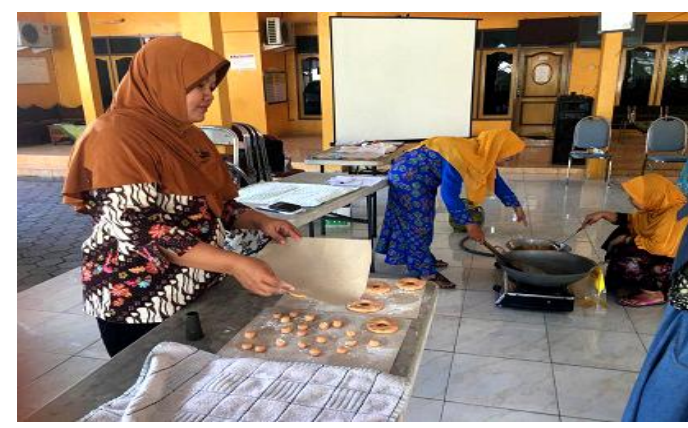

Gambar 5 : Praktek Membuat Kudapan Donat Berbahan Dasar Jambu Biji

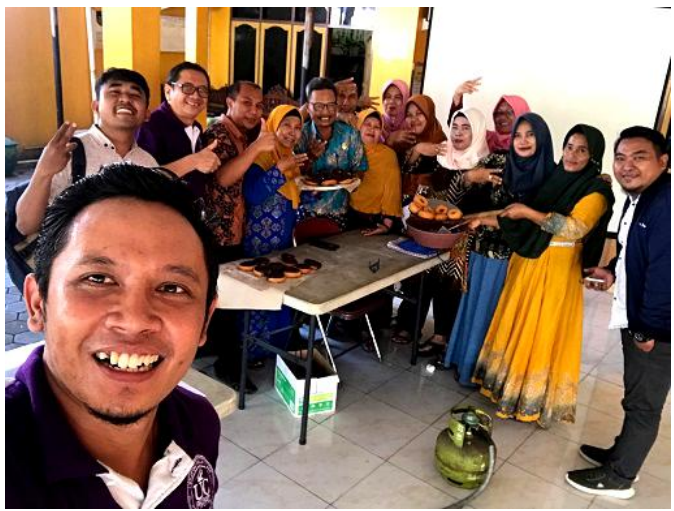

Gambar 6 : Hasil Akhir pendampingan Pelatihan Praktek.

\section{KESIMPULAN}

Pengabdian kepada masyarakat desa Kebaron Tulangan Sidoarjo dengan senang dan antusias dapat meningkatkan pengetahuan dan keterampilan dalam menciptakan produk kudapan yang kreatif untuk menunjang usaha wisata kuliner kebun jambu di desa Kebaron Tulangan Sidoarjo untuk memanfaatkan hasil panen jambu yang melimpah. Implikasi dari pendampingan yang kami lakukan mempunyai dampak yang positif. Peserta bisa mengerti tentang pentingnya sanitasi dan hygiene untuk penjamah makanan agar makanan tersebut sehat, aman bagi yang mengkonsumsi. Peserta bisa menangani bahan makanan dengan baik dan benar. Peserta dapat menghitung biaya bahan makanan dan bisa menghitung harg jual suatu produk. Peserta dapat membuat produk kudapan berupa donat yang menggunakan bahan dari jambu biji yang berwarna merah.

\section{REFERENSI}

Hermanto. 2016 Perhitungan Harga Pokok Pesanan (Job Order Costing) Produk Pesa "BRKT NUMBER PLATE RK56 Pada PT. RAHMAD PERDANA ADHIMETAL"

https://media.neliti.com/publication/16 4558-ID-none.pdf

Rashinda. 2014 "Penggunaan Prosess Costing Method Sebagai Dasar Perhitungan Harga Pokok Produksi Yang Berfungsi Untuk Meningkatkan Akurasi Alokasi Biaya Pada UMKM Ananda Jaya Industri.

eprints.dinus.ac.id/17089/1/jurnal_153 99.pdf

Parimin. (2005). Budidaya: Ragam dan Pemanfaatannya. Penebar Swadaya. Depok.

Regular Training. (2012). Handling Food Safety. Centra Safety. Yogyakarta.

Suryatna. 2015. Peningkatan Kelembutan Tekstur Roti. https://journal.unnes.ac.id/nju/index.ph $\mathrm{p} /$ teknobuga/article/download

Setioaji. 2013. Implementasi Metode Fifo (Fist In Fist Out) Pada Inventory System

https://repository.widyatama.ac.id/xml ui/handle/123456789/2359 
